\title{
Analyzing a denitration process in the context of underground well uranium leaching
}

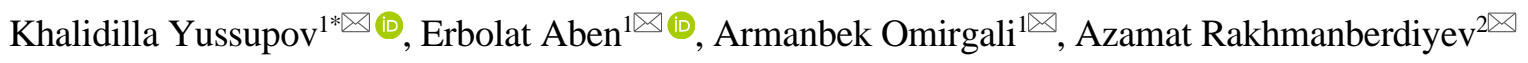 \\ ${ }^{1}$ Satbayev University, Almaty, 50013, Kazakhstan \\ ${ }^{2}$ LLP “Ortalyk", Shymkent, 160023, Kazakhstan \\ *Corresponding author: e-mail yusupov_kh@mail.ru, tel. +77021333330
}

\begin{abstract}
Purpose is to increase a sorbent denitration degree in the context of underground uranium leaching while optimizing reagent concentration as well as a degree of the solution activation on the basis of laboratory research.

Methods. Analysis has been applied as well as scientific generalization of scientific-and-engineering information, laboratory research, statistic processing, and analysis of the research results. The laboratory experiments involved specific mixture to obtain comparative data of sulfuric solution activity and identify optimum degree of the solution activation for denitration. After processing, the solution from activator was analyzed as for its activity; the bulk was poured into a tank for repetitive experiments. First, the research did not involve the solution activation; then, activation with 4-15 minutes was added. Sulfuric acid concentration was 20 and $25 \mathrm{~g} / \mathrm{dm}^{3}$; L-S ratio was 1/8; and washing time was 40, 60, and 120 minutes.

Findings. Laboratory research results have been demonstrated concerning sorbent denitration in terms of varying degrees of activation, sulfuric acid concentration, and response time. It has been demonstrated that it is sufficient for washing solution activation to activate reagent only before extra intensification of a mother solution resulting in the reduced volume of the solution being processed and costs. It has been determined that five- to nine-minute activation period is the efficient interval factoring into the decreased nitrate content in the sorbent after washing to compare with $9-18 \%$ in terms of a basic technique depending upon a reagent concentration.
\end{abstract}

Originality. New dependences of a sorbent denitration degree as well as nitrate content within a solution upon sulfuric acid concentration and the solution activation degree have been defined.

Practical implications. Washing solution activation results in the increased denitration degree of a sorbent to compare with the basic technique. The proposed method is more preferable owing to low capital costs. Moreover, it is integrated easily in the available system being also absolutely sustainable.

Keywords: denitration, sorbent, sorption, desorption, activation, sulfuric acid, uranium

\section{Introduction}

The current progress of science and technology is determined by the unprecedented extent of technological development differing in a very rapid growth of specific power of production facilities. Global consumption of basic energy has become huge [1], [2]. The accelerate progress of nuclear energetics, becoming more important component in power generation, is the feature of the technological revolution [3]-[6]. Such an enormous scale of nuclear power industry needs its adequate natural uranium supply. Hence, uranium demand will increase [7], [8]. It can be satisfied at the expense of traditional methods of industrial ore extraction (i.e. underground mining or open-pit mining); and operation of deposits being of hydrogenic origin mainly being represented by poor ores or lean ones as well as deposits occurring under com- plex mining and geological, and hydrogeological conditions [9]-[12]. Until recently, deposits of group two (i.e. uranium-bearing occurrences of poor and lean ores) have not been involved in the traditional mining methods from the viewpoint of their feasibility. The problem, being very important in terms of the national economic significance, has been almost solved. The last decade is principal as for the development and industrial implementation of geotechnological uranium production called as underground leaching (UL) [13], [14]. For some enterprises, the UL method has become the key one in the process of uranium mining. There is no doubt that the number of such enterprises will increase in future.

Currently, poor deposits of hydrogenic genesis, occurring within the permeable argillo-arenaceous formations of depression zones of the earth's crust, are the raw materials base 
of enterprises, mining uranium using UL method [15]. The abovementioned results in the decreased uranium production while leaching; rather often, dramatic reduction of the uranium content within a PR solution is observed after a minor period of the uranium lump development [16]. At the same time, operating schedule to process PSs within a shop treating PSs (WTPSS), involves uranium sorption on strong base anion-exchange resin in sorption pressurized columns of CHK-3м type; fortification of the saturated sorbent by means of PSs within the areas of SDK-1500 type columns; counterflow nitrate uranium sorption in desorption areas of SDK-1500 columns; sorbent denitrating and washing within columns of KI/DNK-2000 type; and the regenerated sorbent loading in SNK-3M columns [17].

To a greater extent, the regularities of desorption processes are similar to the schemes of sorption processes. In common with sorption, desorption period of element in terms of continuous supply of desorbing solutions (DRs) to a column with the saturated ionite is divided into two stages: formation period of a front of equilibrium concentrations; and a period of its motion along the sorbent towards solution motion. Sorption method is based upon ion-exchange processes a well as upon selectivity of the certain type of ionexchange resins relative to uranium compounds being a part of the solution or slurry. Either resin or absorbent coal is applied for sorption. In this context, ion-exchange resin is used in the form of small spheral crystals being introduced in the process differently: as a stationary bed, transferred sporadically, or circulating continuously together with the solution of matters. For the most part, uranium compounds are sorbed selectively by dozens and thousands of resin crystals at their surface, being washed with the solution; in a very small way, the procedure is typical for compounds of some other elements being available within the solution. Predominantly, ferric iron is sorbed on resin together with uranium.

In the context of all mass exchange processes (i.e. sorption), their intensification is achieved with the help of the forced stirring of reagents using mechanical mixers or air barbotage. In terms of sorption partition, a degree of uranium extraction from PSs depends upon their salt composition, acidity, and uranium content. However, it is more than $90 \%$ in the main. Anionite capacity varies greatly (i.e. 20 up to $100 \mathrm{~kg} / \mathrm{t}$ ). Residual uranium concentrations are 1 to $3 \mathrm{mg} / \mathrm{l}$ within the sorption mother solutions.

Desorption process is possible in the context of organization of the saturated ionite-DS contact [18]. The sorbed metal desorption is the most difficult and labour-intensive processing step. Desorption relies upon the capacity of certain chemical compounds to displace the elements, being sorbed, from the ionite structure replacing them by corresponding counter-ions; nitrate ions are meant in the specific case.

To a greater extent, the regularities of a desorption process are similar to the schemes of sorption processes. Moreover, like in terms of sorption, a period of an element desorption in terms of continuous supply of DSs to a column with the saturated ionite, is divided into two stages: a period of the formation of an equilibrium concentrations front; and a period of its motion along the sorbent towards direction of the solution motion.

Effective uranium desorption involves the use of reagents, having the greatest depressive influence on its sorption.

Nitrate method also belongs to a class of displacing desorption techniques. After uranium desorption is over, anionite should be transferred to a working ionic form.
Currently, residual nitrate ion content in sorbent is $6-11 \%$; in this context, sulfuric acid concentration varies from 25 up to $36 \%$. Hence, denitration degree is not sufficient. The abovementioned results in the resin deteriorating as for the uranium, loss of nitrate ions, and the increased consumption of ammonia nitrate as well as sulfuric acid consequently.

\subsection{Current state of denitration process at the research subject}

Uranium deposit Mynkunduk is the research subject. The occurrence is within Betpak-Dala plateau being a large plain upland limited northerly and westerly by the dissected erosion scarp with up to $80-100 \mathrm{~m}$ height; in the south, it is inclined gently to the Shu River valley of the Republic of Kazakhstan. Uranium mineralization at Mynkunduk deposit occurs within the permeable sand levels; it is controlled by epy boundaries of layer oxidation being parts of one regional oxidizing front. Generally, two chalk beds are the ore-bearing ones at the deposit. They are Mynkunduk bed (Lower Touronian stage) and Inkuduk bed (Upper Touronian-Coniacian-Santonian stage). Within Tsentralny site, uranium mineralization is connected with Mynkunduk level. The Tsentralny site is characterized by the availability of rather thick gray clay lentils observed in the lower share of the level as well as along its section on the whole. The abovementioned stipulates significant lithofacial heterogeneity of Mynkunduk level. Integrally, section of the level corresponds to the determined regularity: lower sublevel is represented by channel and mainstream facies; bar and channel sand deposits prevail in its upper sublevel. In this context, role of clay levels becomes more important from east to west; thickness of the layers as well as their extension is observed. The major uranium share is in the dispersed easily extracted form, disseminated within loose permeable porous sand aggregate. Together with finely crystalline pyrite, uranium minerals form the thinnest powdering on fragmentary grains and thicker powdering (i.e. incrustations) on aggregate pyrite grains. In some cases, they can even act as cement.

Denitration purpose is to regenerate sorbent into initial (i.e. sulfate) form being applicable for a sorption process as well as decrease specific consumption of desorbing agent at the expense of recycle and later use of nitrate ions $\mathrm{NO}_{3}^{-}$[19].

Anionite conversion from a nitrate form into sulfate one is described with the help of following chemical equation:

$$
2\left(\mathrm{R}_{4} \mathrm{~N}\right)^{+-}\left(\mathrm{NO}_{3}\right)^{-}+\mathrm{SO}_{4}{ }^{2-}=\left(\mathrm{R}_{4} \mathrm{~N}\right)_{2}{ }^{+}-\left(\mathrm{SO}_{4}\right)^{2-}+2 \mathrm{NO}_{3}{ }^{-}
$$

Denitration of PS processing has been organized in DNK 2000 columns being mass-exchange sorption-type devices with vertical drainage system of reusable solutions (Fig. 1).

To process the available amount of the desorbed ionite, the operation procedure involves modular use of DNK columns functioning as follows:

- supply of initial denitrating solution to the column base;

- delivery of a denitration barren solution from the column to a unit where desorbing solutions are prepared;

- discharge of the denitrated solution from the column for further processing step.

Denitrating solution is prepared on the basis of washing barren solutions, washing unit of the regenerated sorbent, and filtration barren solutions intensified additionally up to $25-35 \mathrm{~g} / \mathrm{dm}^{3}$ strength with the help of the concentrated sulfuric acid solution supplied from a warehouse of liquid reagents. Horizontal mixture is applied to intensify agitation of the solutions. 


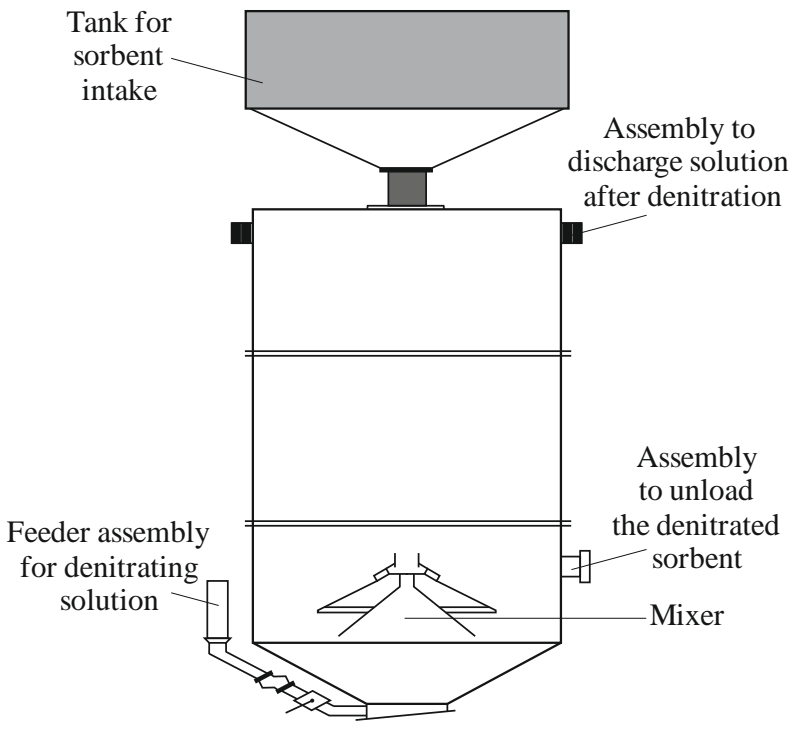

Figure 1. DNK 2000 column to denitrate sorbent

Sulfuric acid concentration is the most important influential factor for denitration process. The increased its content forces denitration degree significantly.

On the other hand, increase in sulfuric acid concentration in the denitrating solution results in its increased content within denitration barren solution as well as in the desorbing solution.

Sorbent denitration is a sorption-desorption process influenced by numerous factors. First, it concerns a type of desorbing agent and its concentration. In this context, sulfuric acid is meant; sulfate particularly; and hydrosulfate ions especially which content increases along with the increase in sulfuric acid concentration.

Moreover, following factors also influence a denitration process:

- operating space-column diameter ratio forming denitration front;

- amount of the propelled resin and the process frequency.

The factors are interdependent. Among other things, decrease in the propelled resin amount results in the increased frequency of the resin contact with a live solution portion approaching continuous process of the denitration (ideal conditions are meant):

- linear velocity of denitrating solution supply. Increase in a linear velocity heightens concentration difference of the transferred ions;

- specific consumption of the denitrating solution per resin amount;

- temperature.

These are the basic factors influencing anionite denitration under the production conditions.

If sorption modes (i.e. amount of the propelled anionite; frequency; capacity etc.) influence operational characteristics of processing area, then running characteristics of denitration as well as desorption are identified in accordance with the sorption process stage. First of all, optimization of the active scheme of a pregnant solution processing, using apparatus retooling of regeneration unit of ion-exchange material, involves more qualitative and efficient implementation of the main equipment. Currently, the process stage operation applies modular mode, i.e. independent use of denitration columns.

Advantages of the operation of regeneration devices are as follows: no agitation of anionite from different production

modules; minimization of shutdown of processes as well as idle equipment periods in repair cases or if part substitution is required; and possibility to organize operation of process stages in terms of various parameters and conditions. However, low degree of a sorbent conversion (i.e. no more than 60\%) is the disadvantage of individual use of denitration columns.

It is possible to note than insufficient completeness of anionite denitration first depends upon low chemical activity of the process itself being stipulated by higher sorbent affinity for nitrate ions. Hence, the authors have proposed a technique of mechanical activation of a washing solution which helped increase a degree of the sorbent denitration.

\subsection{Purpose of the research and its tasks}

Purpose of the research is to increase a degree of sorbent denitration in the context of underground uranium leaching owing to the optimization of reagent concentration as well as activation degree of the solution based upon the laboratory studies.

The research tasks are as follows:

- to develop a procedure and manufacture a device for laboratory works;

- to identify dependences of nitrate content in resin upon the activation and washdown periods in terms of different concentrations of sulfuric acid;

- to determine changes in nitrate concentration in resin depending upon the activation period as well as washing if different amounts of washing solution are activated;

- to elaborate and analyze the laboratory research results.

\section{The laboratory research procedure}

The two methods were applied to carry out the laboratory studies using: a model denitration device and a mixer. The laboratory facility, shown in Figure 2, consists of a pump and a column to denitrate a tank for solution. The laboratory mixture, shown in Figure 3, consists of a motor, propeller agitator, and tank for solution. The paper represents the results of laboratory studies with the use of a mixer. The key problem, being solved in the process of the laboratory research, is to obtain comparative data of sulfuric solution activity and identify the required degree of the solution activation for denitration.

(a)

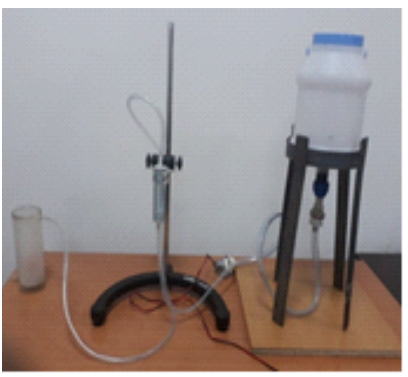

Figure 2. Laboratory device to denitrate resin: (a) assembled facility; (b) model of the denitration column with sorbent

Resin for the denitration was divided into thirty-nine 50gram test portions and six 35-gram test portions. Since the paper represents laboratory studies involving a mixture, twenty-eight 50-gram test portions were applied. The laboratory research was carried out with $25 \mathrm{~g} / \mathrm{dm}^{3}$ sulfuric acid concentration, and $20 \mathrm{~g} / \mathrm{dm}^{3} ; 1 / 8 \mathrm{l}-\mathrm{s}$ ratio; and 40-, 60-, and 120-minute washing time. 


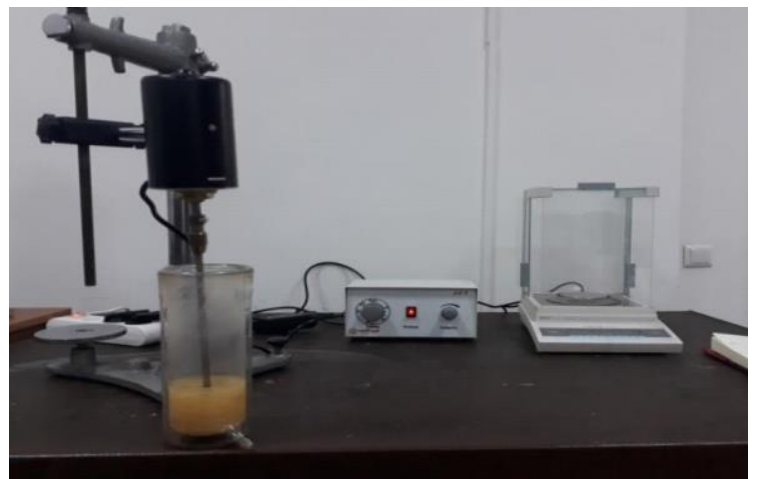

Figure 3. Laboratory mixer with sorbent

First, the laboratory studies did not involve the solution activation; then, activation was performed during 4, 5, 6, 8, 10, 12, and 15 minutes. After the resin washing, it was delivered to a laboratory to determine residual nitrate concentration.

The solution was activated with the help of a laboratory device consisting of a pump, a current activator, a tank for solution, and a drawoff tap [20]. The procedure to process solution by means of activator is as follows. A working sulfuric solution is tanked, and electric motor of a pump is started. The pressurized solution passes through the activator, and comes back to the tank.

Every time after next in turn amount of sulfuric solution is processes, it is tanked separately; the device is washed with water to avoid corrosion of the pump parts.

To process following amount, 2.0 liters of a solution with the initial concentration are tanked. Then, the pump is started for 8-10 seconds to make a mixture with residual washing water during motion.

The solution is the initial one relative to which comparison is made with activity of a solution processed finally by means of activator.

When the processing is completed, the solution from activator is analyzed as for its activity; the bulk is tanked for repetitive experiments after definite time. It should be noted that industrial activation of the whole washing solution needs significant material cost; hence, stage one of the laboratory research involves reagent activation only.

\section{Results and discussion}

Laboratory analysis of resin from the mine has shown that nitrate concentration is $186.03 \mathrm{~g} / \mathrm{l}$. The resin was sampled at a Tsentralny Mynkunduk mine. Strong-base anionite of Ambersep 920 USO4 type has been applied as well as macropore cross-linked polystrene with $735 \mathrm{~g} / \mathrm{l}$ specific gravity; 750-950 $\mu \mathrm{mol}$ average particle size; and concentration of less than $0.710 \mathrm{~mm}$ fine crystals. Large crystals (i.e. those being larger than $1.180 \mathrm{~mm}$ ) amounted to $5 \%$; moisture content was $4 \% ; \mathrm{H}_{2} \mathrm{SO}_{4}$ content was no less than $92.5 \%$; and ammonia nitrate content was $60 \%$. Sulfuric acid has also been selected for the desorption process; expressed in terms of nitrogen on a dry basis, total concentration of nitric nitrogen and ammonium nitrogen was no less than $34.0 \%$.

Table 1 demonstrates results of the laboratory studies carried out using a mixer.

Processing of the data, represented in Table 1, has helped obtain changes in the nitrate content in resin depending upon activation period as well as washdown period, if sulfuric acid concentration is $20 \mathrm{~g} / \mathrm{l}$ (Fig. 4).
Table 1. Results of the laboratory studies carried out with the use of a mixer

\begin{tabular}{ccc}
\hline $\begin{array}{c}\text { Activation period, } \\
\text { minutes }\end{array}$ & $\begin{array}{c}\mathrm{H}_{2} \mathrm{SO}_{4} \\
\text { concentration, g/l }\end{array}$ & $\begin{array}{c}\text { Washing period, } \\
\text { minutes }\end{array}$ \\
\hline No activation & 20 & 60 \\
No activation & 20 & 40 \\
5 & 20 & 40 \\
6 & 20 & 60 \\
8 & 20 & 60 \\
10 & 20 & 40 \\
12 & 20 & 40 \\
15 & 20 & 40 \\
12 & 20 & 60 \\
15 & 20 & 60 \\
No activation & 25 & 60 \\
No activation & 25 & 40 \\
5 & 25 & 40 \\
6 & 25 & 60 \\
8 & 25 & 60 \\
10 & 25 & 40 \\
12 & 25 & 40 \\
15 & 25 & 40 \\
12 & 25 & 60 \\
15 & 25 & 60 \\
\hline
\end{tabular}

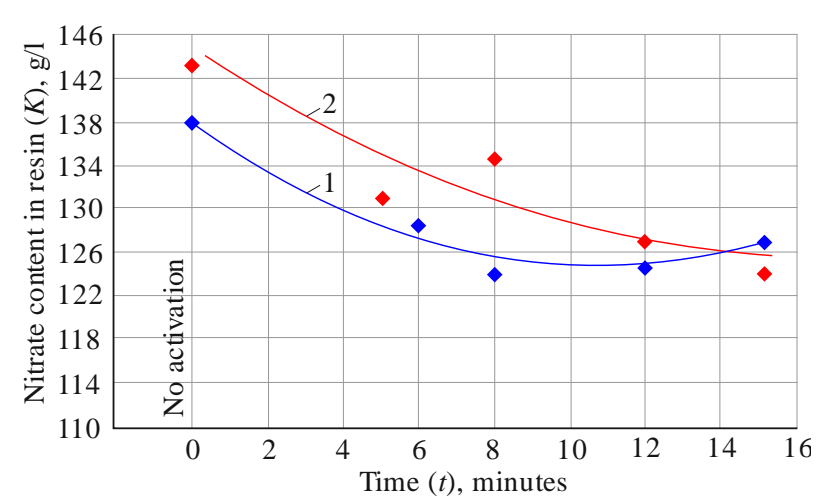

Figure 4. Changes in nitrate content in resin (K) depending upon activation time (t) as well as washdown period in terms of $20 \mathrm{~g} / \mathrm{l}$ sulfuric acid concentration: 1 - 60-minute of activation; 2 - 40-minute activation

Data analysis of the laboratory research has shown that if washdown lasts 40 minutes and sulfuric acid concentration is $20 \mathrm{~g} / \mathrm{l}$, then the solution activation results in the maximum decrease of nitrate content being only $13 \%$ to compare with the traditional method; average decrease was $7 \%$. In terms of 60-minute washdown and up to 8-minute solution activation, maximum nitrate content decrease turned out to be $10 \%$ to compare with the traditional technique; average decrease was $8.5 \%$. Increase in sulfuric acid concentration up to $25 \mathrm{~g} / \mathrm{l}$ along with the 40-minute washdown period has resulted in $18 \%$ maximum decrease in nitrate content to compare with the traditional method; average decrease was $9 \%$. Maximum nitrate decrease is achieved if the solution is activated 5 to 9 minutes; further 10-15-minute increase in activation period factors into the decreased nitrate content being $5 \%$ on average.

Concurrently, the Table 1 explains that $20 \mathrm{~g} / \mathrm{l}$ sulfuric acid concentration results in the increased washdown degree. In turn, $25 \mathrm{~g} / \mathrm{l}$ concentration decreases the washdown degree, i.e. not always increase in sulfuric acid concentration delivers a positive result. The decreased degree of resin denitration, depended upon time increment of a solution activation, is explained by the reagent heating and evaporating during its activation. 
Processing of the data, represented by the Table 1, demonstrates changes in nitrate content in resin depending upon the activation and washdown periods if sulfuric acid concentration is $25 \mathrm{~g} / \mathrm{l}$ (Fig. 5).

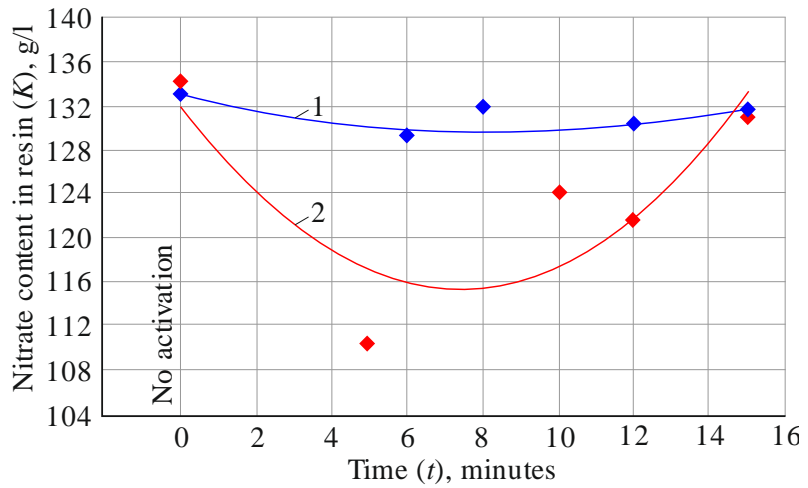

Figure 5. Changes in nitrate content in resin (K) depending upon activation time (t) as well as washdown period in terms of $25 \mathrm{~g} / \mathrm{l}$ sulfuric acid concentration: 1 - 60-minute of activation; 2 - 40-minute activation

Stage two of the research involved 30, 50, 80 and $100 \%$ activation of a washing solution. In this context, sulfuric acid concentration was $25 \mathrm{~g} / \mathrm{l}$; and washing period amounted to 60 minutes. Table 2 demonstrates results of the laboratory studies carried out using a mixer.

Table 2. Results of laboratory studies carried out with the use of a mixer

\begin{tabular}{|c|c|c|c|}
\hline $\begin{array}{c}\text { Activation period } \\
\text { (minutes)/solution, } \%\end{array}$ & $\begin{array}{c}\mathrm{H}_{2} \mathrm{SO}_{4} \\
\text { concentra- } \\
\text { tion, } \mathrm{g} / \mathrm{l} \\
\end{array}$ & $\begin{array}{l}\text { Washing } \\
\text { period, } \\
\text { minutes }\end{array}$ & $\begin{array}{c}\text { Nitrate } \\
\text { content, } \\
\mathrm{g} / \mathrm{l}\end{array}$ \\
\hline $\begin{array}{l}\text { six-minute activation } \\
\text { of } 30 \% \text { solution }\end{array}$ & 25 & 60 & 124.0 \\
\hline $\begin{array}{l}\text { six-minute activation } \\
\text { of } 50 \% \text { solution }\end{array}$ & 25 & 60 & 117.1 \\
\hline $\begin{array}{l}\text { six-minute activation } \\
\text { of } 80 \% \text { solution }\end{array}$ & 25 & 60 & 115.9 \\
\hline $\begin{array}{l}\text { six-minute activation } \\
\text { of } 100 \% \text { solution }\end{array}$ & 25 & 60 & 117.4 \\
\hline $\begin{array}{l}\text { eight-minute activation } \\
\text { of } 30 \% \text { solution }\end{array}$ & 25 & 40 & 127.3 \\
\hline $\begin{array}{l}\text { eight-minute activation } \\
\text { of } 50 \% \text { solution }\end{array}$ & 25 & 40 & 124.0 \\
\hline $\begin{array}{l}\text { eight-minute activation } \\
\text { of } 80 \% \text { solution }\end{array}$ & 25 & 40 & 119.5 \\
\hline $\begin{array}{l}\text { eight-minute activation } \\
\text { of } 100 \% \text { solution }\end{array}$ & 25 & 40 & 117.2 \\
\hline
\end{tabular}

According to Table 2, 30\% activation of washing solution factors into more than $7 \%$ decrease in nitrate content to compare with the traditional method. $50 \%$ and $100 \%$ solution activation results in the $12 \%$ decrease of nitrate content in resin to compare with the traditional technique. Decrease in washdown period down to 40 minutes as well as activation time increment up to 80 minutes leads to similar results.

Processing of the Table 2 data has made it possible to obtain changes in nitrate content in resin depending upon the activation and washdown periods if sulfuric acid concentration is $25 \mathrm{~g} / \mathrm{l}$ and different amounts of a washing solution are activated (Fig. 6). As it is understood from Figure 6, nitrate content in resin depends upon different solution amounts. Up to $60 \%$ activation of the whole supplied solution demonstrates significant decrease of nitrates in sorbent.

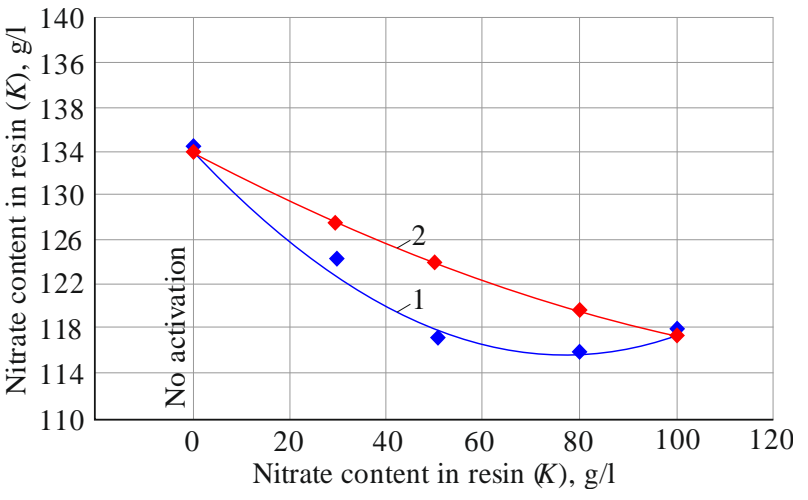

Figure 6. Changes in nitrate content in resin (K) depending upon activation of different amounts of a washing solution: 1 - 6-minutes of activation; $2-8$ minutes activation

Further activation of the supplied solution (i.e. more than $60 \%$ ) results in minor nitrate decrease; sometimes, nitrate increase in the sorbent is observed. Comparison of denitration degree, involving washing solution with a reagent activation only and activation of different shares of the whole washing solution (Tables 1 and 2), shows average 7-8\% difference. The abovementioned can be considered as similar results.

\section{Conclusions}

The operating procedure of mechanical activation of a washing solution increases denitration degree of a sorbent. Moreover, it excludes the necessity to activate the whole amount of a washing solution. Minimization of nitrate concentration in sorbent is observed if up to $60 \%$ of the whole washing solution is activated.

It has been proved that reagent activation before PS intensification is quite sufficient to activate a washing solution. Hence, decrease in the processed solution amount is observed as well as expenditures connected with sorbent denitration.

Increment of the time, required to activate a washing solution, results in the decreased degree of a sorbent denitration which can be explained by a reagent heating and evaporating during its activation. In this context, denitration degree does not experience its decrease owing to the increased activity of the washing solution. 5-9-minute reagent activation is considered as the efficient time resulting in the decreased nitrate content in the sorbent after washdown to compare with 9-18\% demonstrated by the basic process depending upon a reagent concentration.

In the process of the washing solution activation, increase in sulfuric acid concentration up to $20 \mathrm{~g} / \mathrm{l}$ factors into a higher washdown degree. Its further increase results in the decreased degree of a sorbent washdown, i.e. not always increase in sulfuric acid concentration delivers a positive result.

\section{Acknowledgements}

The studies have been carried out as a part of research activities based on economic agreement "Developing a method to intensify denitrating and leaching processes under the conditions of Tsentralny site at Mynkunduk deposit with LLP "Ortalyk". The authors pay thanks to employees of Tsentralny Mynkunduk mine, LLP "Ortalyk", and S.A. Yusupov, the main scientist researcher for their assistance and valuable guidelines while carrying-out of the studies. 


\section{References}

[1] Platzer, M.F., \& Sarigul-Klijn, N. (2021). Current status of global energy consumption, production, and storage. SpringerBriefs in Applied Sciences and Technology, 11-16. https://doi.org/10.1007/978-3030-58244-9 2

[2] Fathi, B., Ashena, M., \& Bahari, A.R. (2021). Energy, environmental, and economic efficiency in fossil fuel exporting countries: A modified data envelopment analysis approach. Sustainable Production and Consumption, (926), 588-596. https://doi.org/10.1016/j.spc.2020.12.030

[3] Rong, J., \& Liu, Z. (2020). Development and prospect of advanced nuclear energy technology. Atomic Energy Science and Technology, 54(9), 1638-1643. https://doi.org/10.7538/yzk.2020.youxian.0348

[4] Sofu, T. (2018). A roadmap for nuclear energy technology. AIP Conference Proceedings, (1924), 020004. https://doi.org/10.1063/1.5020284

[5] Futter, A., \& Zala, B. (2019). Emerging non-nuclear technology and the future of the global nuclear order. Nuclear Disarmament: A Critical Assessment, 207-223. https://doi.org/10.4324/9780429026126-13

[6] Galiyev, D.A., Uteshov, E.T., \& Tekenova, A.T. (2020). Digitalization of technological and organizational processes of mining operations due to the implementation of the installation system and accounting the key indicators. News of the National Academy of Sciences of the Republic of Kazakhstan, Series of Geology and Technical Sciences, 5(443), 47-53. https://doi.org/10.32014/2020.2518-170x.103

[7] Lyashenko, V.I., Franchuk, V.P., \& Kisly, B.P. (2015). Reengineering of technical-and-technological structur e of uranium mine. Gornyi Zhurnal, (1). https://doi.org/10.17580/gzh.2015.01.05

[8] Kuandykov, T., Nauryzbayeva, D., Yelemessov, K., Karmanov, T., Kakimov, U., \& Kolga, A. (2020). Development and justification of a hydro-impulse method for increasing ore permeability in conditions of uranium borehole production. News of the National Academy of Sciences of the Republic of Kazakhstan, Series of Geology and Technical Sciences, (6), 126-133.

[9] Nazarova, Z.M., Ovseychuk, V.A., \& Lementa, O.Yu. (2016). Rynok urana: Sovremennoe sostoyanie, problemy i perspektivy ego razvitiya. Problemy Sovremennoy Ekonomiki, (2), 159-162.

[10] Rysbekov, K., Toktarov, A., Kalybekov, T., Moldabayev, S., Yessezhulov, T., \& Bakhmagambetova, G. (2020). Mine planning subject

to prepared ore reserves rationing. E3S Web of Conference, (168), 00016. https://doi.org/10.1051/e3sconf/202016800016

[11] Stupnik, M., Kolosov, V., Kalinichenko, V., \& Pismennyi, S. (2014). Physical modeling of waste inclusions stability during mining of complex structured deposits. Progressive Technologies of Coal, Coalbed Methane, and Ores Mining, 25-30. https://doi.org/10.1201/b17547

[12] Kalybekov, T., Rysbekov, K., Nauryzbayeva, D., Toktarov, A., \& Zhakypbek, Y. (2020). Substantiation of averaging the content of mined ores with account of their readiness for mining. E3S Web of Conferences, (201), 01039. https://doi.org/10.1051/e3sconf/202020101039

[13] Sukhodolov, A.P. (2010). Mirovye zapasy urana: Perspektivy syr'yevogo obespecheniya atomnoy energetiki. Izvestiya Irkutskoy Gosudarstvennoy Ekonomicheskoy Akademii, 4(72), 166-169.

[14] Boytsov, A. (2014). Worldwide ISL uranium mining outlook: Presentation. Proceedings of the International Symposium on Uranium Raw Material for the Nuclear Fuel Cycle: Exploration, Mining, Production, Supply and Demand, Economics and Environmental, 1-23.

[15] Lyashenko, V.I. (2001). Improvement of mining of mineral resources with combined leaching methods. Gornyi Zhurnal, (1), 28-35.

[16] Yusupov, Kh.A., \& Dzhakupov, D. (2017). Issledovanie primeneniya biftorida ammoniya dlya khimicheskoy obrabotki skvazhin. Gornyy Zhurnal, (4), 57-59.

[17] Tekhnologicheskiy reglament dobychi i pererabotki urana (rudnik podzemnogo skvazhinnogo vyshchelachivaniya urana mestorozhdenich Tsentral'nyy Mynkuduk-pererabatyvayushchiy kompleks). (2014). Almaty, Kazakhstan: TOO "DP "Ortalyk", $51 \mathrm{~s}$

[18] Volkov, V.P. (2014). Sorbtsionnye protsessy deystvuyushchikh proizvodstv. Moskva, Rossiya: Ruda i metally, $160 \mathrm{~s}$.

[19] Optimizatsiya parametrorv desorbtsii i denitratsii s tsel'yu snizheniya raskhoda ammiachnoy selitry na uranodobyvayushchem predpriyatiy TOO "DP "Ortalyk". (2018). Otchet o nauchno-issledovatel'skoy rabote. Almaty, Kazakhstan: Institut vysokikh tekhnologiy, $34 \mathrm{~s}$.

[20] Aben, E., Markenbayev, Z., Khairullaev, N., Myrzakhmetov, S., \& Aben, K. (2019). Study of change in the leaching solution activity after treatment with a cavitator. Mining of Mineral Deposits, 13(4), 114-120. https://doi.org/10.33271/mining13.04.114

\section{Дослідження процесу денітрації при підземному свердловинному вилуговуванні урану}

\section{Х. Юсупов, Е. Абен, А. Оміргалі, А. Рахманбердієв}

Мета. Підвищення ступеня денітрації сорбенту при підземному вилуговуванні урану за рахунок оптимізації концентрату реагенту та ступеня активації розчину на основі лабораторних досліджень.

Методика. Використано аналіз і наукове узагальнення науково-технічної інформації, лабораторні дослідження, статистична обробка та аналіз результатів досліджень. Лабораторні дослідження проводились на спеціально розробленій мішалці для отримання порівняльних даних активності сірчанокислотного розчину і визначення оптимального ступеня активації розчину для денітрації. Після обробки розчин з активатора брали на дослідження активності, а основний об'єм зливали в ємність для проведення повторних експериментів. Дослідження проводилися без активацій розчину, потім з активацією від 4 до 15 хвилин. Концентрація сірчаної кислоти - 20 і 25 г/дм³ співвідношення Р/Т - 1/8, час промивання - 40, 60 і 120 хвилин.

Результати. Наведено результати лабораторних досліджень з денітрації сорбенту при різному ступені активації, концентрації сірчаної кислоти і часу реакції. Встановлено, що для активації розчину для промивання досить активувати лише реагент перед дозміцненням маточного розчину, в результаті чого зменшується об'єм оброблюваного розчину і витрати. Визначено, що ефективним часом активації реагенту є час від 5 до 9 хвилин, що призводить до зниження вмісту нітрату в сорбенті після промивання у порівнянні з базовою технологією від 9 до 18\% залежно від концентрації реагенту.

Наукова новизна. Встановлено нові залежності ступеня денітрації сорбенту і вмісту нітрату в розчині від концентрації сірчаної кислоти та ступеня активації розчину.

Практична значимість. Активація промивного розчину призводить до підвищення ступеня денітрації сорбенту у порівнянні з базовою технологією. Запропонована технологія відрізняється низькими капітальними витратами, легко інтегрується в існуючу систему та екологічно абсолютно безпечна.

Ключові слова: денітрація, сорбент, сорбція, десорбиія, активація, сірчана кислота, уран

\section{Исследование процесса денитрации при подземном скважинном выщелачивании урана}

\section{Х. Юсупов, Е. Абен, А. Омиргали, А. Рахманбердиев}

Цель. Повышение степени денитрации сорбента при подземном выщелачивании урана за счет оптимизации концентрата реагента и степени активации раствора на основе лабораторных исследований.

Методика. Использованы анализ и научное обобщение научно-технической информации, лабораторные исследования, статистическая обработка и анализ результатов исследований. Лабораторные исследования проводились на специально разработанной мешалке для получение сравнительных данных активности сернокислотного раствора и определения оптимальной степени активации раствора для денитрации. После обработки раствор из активатора брали на исследование активности, а основной объем сливали в емкость для проведения повторных экспериментов. Исследования проводились без активаций раствора, затем с активацией от 4 до 15 минут. Концентрация серной кислоты - 20 и 25 г/дм³, соотношение Ж/Т - 1/8, время промывки - 40, 60 и 120 минут. 
Результаты. Приведены результаты лабораторных исследований по денитрации сорбента при различной степени активации, концентрации серной кислоты и времени реакции. Установлено, что для активации промывочного раствора достаточно активировать только реагент перед доукреплением маточного раствора, в результате чего уменьшается объем обрабатываемого раствора и затраты. Определено, что эффективным временем активации реагента является время от 5 до 9 минут, что приводит к снижению содержания нитрата в сорбенте после промывки по сравнению с базовой технологией от 9 до $18 \%$ в зависимости от концентрации реагента.

Научная новизна. Установлены новые зависимости степени денитрации сорбента и содержания нитрата в растворе от концентрации серной кислоты и степени активации раствора.

Практическая значимость. Активация промывочного раствора приводит к повышению степени денитрации сорбента по сравнению с базовой технологией. Предлагаемая технология отличается низкими капитальными затратами, легко интегрируется в существующую систему и экологически абсолютно безопасна.

Ключевые слова: денитрачия, сорбент, сорбиия, десорбиия, активация, серная кислота, уран 